\title{
Association of FGFR2 rs2981582, SIRT1 rs12778366, STAT3 rs744166 gene polymorphisms with pituitary adenoma
}

\author{
BRIGITA GLEBAUSKIENE ${ }^{1}$, ALVITA VILKEVICIUTE ${ }^{2}$, RASA LIUTKEVICIENE ${ }^{1,2}$, \\ SILVIJA JAKSTIENE ${ }^{3}$, LORESA KRIAUCIUNIENE $^{1,2}$, REDA ZEMAITIENE $^{1}$ and DALIA ZALIUNIENE ${ }^{1}$ \\ ${ }^{1}$ Department of Ophthalmology; ${ }^{2}$ Neuroscience Institute; ${ }^{3}$ Department of Radiology, \\ Medical Academy, Lithuanian University of Health Sciences, LT-50161 Kaunas, Lithuania
}

Received August 22, 2016; Accepted January 13, 2017

DOI: $10.3892 / \mathrm{ol} .2017 .5840$

\begin{abstract}
The aim of the present study was to determine the association between sirtuin 1 (SIRT1), fibroblast growth factor receptor 2 (FGFR2) and signal transducer and activator of transcription 3 (STAT3) polymorphisms, and pituitary adenoma (PA) development, invasiveness, hormonal activity and recurrence. The present study included 143 patients with a diagnosis of PA. The reference group involved 808 healthy subjects. The genotyping of SIRT1 rs12778366, FGFR2 rs2981582 and STAT3 rs744166 was performed using the quantitative polymerase chain reaction method. The SIRT1 rs12778366 polymorphism analysis in the overall group revealed differences in the genotype distribution between patients with PA and control group subjects. The $r s 12778366 \mathrm{~T} / \mathrm{C}$ genotype was observed to be different in non-invasive, non-recurrent and inactive PA subgroups compared with the control group, while the $\mathrm{C} / \mathrm{C}$ genotype was observed to be different in invasive, recurrent and active PA subgroups compared with the control group. STAT3 rs744166 polymorphism analysis in the overall group revealed differences in the genotype distribution between patients with PA and the control groups. The $r s 744166 \mathrm{G} / \mathrm{G}$ genotype was observed to be different in invasive, non-recurrent and active PA subgroups compared with the control group, while the $r s 744166 \mathrm{~A} / \mathrm{A}$ genotype was observed to be different in the active PA subgroup compared with the control group, and was also different in terms of invasiveness and recurrence in PA subgroups. The present study demonstrated that SIRT1 rs 12778366 is associated with pituitary adenoma development while STAT3 rs744166 is associated with PA invasiveness, hormonal activity and recurrence.
\end{abstract}

Correspondence to: Dr Brigita Glebauskiene, Department of Ophthalmology, Medical Academy, Lithuanian University of Health Sciences, Eiveniu 2, LT-50161 Kaunas, Lithuania

E-mail: bglebauskiene@gmail.com

Key words: pituitary adenoma, gene polymorphism, fibroblast growth factor receptor 2 rs2981582, sirtuin 1 rs12778366, signal transducer and activator of transcription 3 rs744166

\section{Introduction}

Pituitary adenomas (PAs), located in a bone cavity termed the sella turcica, are one of the most common types of intracranial neoplasms, with reported estimated prevalence rates ranging between 14.4 and $22.5 \%$ in pooled autopsy and radiological series, respectively (1). Although the majority of PAs are benign, it is not uncommon for them to grow large and extend locally into the surrounding structures, invading the sphenoid bone inferiorly, the cavernous sinus laterally $(2-7,8)$ and/or compressing the optic chiasm, if the direction of expansion is suprasellar, thus resulting in neurological complications, including headache and visual impairment (9-17). Certain types of PA are extremely invasive and may cause extensive destruction of the skull base (18). Investigation of tumour invasiveness is required, as this affects the management and prognosis of PA (19). The aim of the present study was to identify possible genes involved in PA tumourigenesis, which may serve as potential diagnostic and prognostic molecular markers. The present study selected 3 genes, sirtuin 1 (SIRT1), fibroblast growth factor receptor 2 (FGFR2) and signal transducer and activator of transcription 3 (STAT3), which are associated with different types of cancer, but are connected in pathogenic processes (20-23).

SIRT1 is a nicotinamide adenine dinucleotide-dependent histone deacetylase (HDAC) (24), which serves an important role in maintaining the balance between cell death and survival through targeting the Ku70-B-cell lymphoma-like protein 4 pathway $(25)$, p53 $(26,27)$ and forkhead box O3 (28), among others. A significant increase in the level of SIRT1 in hepatocellular carcinoma (29), breast cancer (30), prostate cancer (31), ovarian cancer (32), gastric cancer (33), colon cancer (34), glioblastoma (35) and lymphoma (36) was previously suggested to be associated with the development and invasion of these tumours. Furthermore, the rs 12778366 polymorphism of the SIRTI gene was found to be associated with breast cancer (37).

FGFR2 is a member of the FGFR family of tyrosine kinase receptors and participates in the process of tumourigenesis by inducing mitogenic and survival signals, and promoting invasiveness and angiogenesis (38). If cancer cells overexpress an FGFR with altered ligand-binding specificity, FGFs, secreted from neighbouring cells, stimulate the cancer cells, creating a paracrine loop (38). FGFR2 was previously revealed to be 
overexpressed in bladder (39) and lung cancer (40). Additionally, the importance of the FGFR2 rs2981582 gene polymorphism was investigated in breast (41-50) and prostate cancer (51).

STAT3 is activated in tumour cells and numerous immune cells of the tumour microenvironment, and is associated with tumour cell proliferation, invasion and angiogenesis (52-54). The effect of STAT3 was previously studied in the tumour development of colorectal adenocarcinoma (55), hepatocellular carcinoma (56), multiple myeloma (57), glioblastoma (58), prostate cancer (59), and head and neck cancer (60). The STAT3 rs744166 polymorphism was also evaluated in gastric $(61,62)$, colon (63) and lung cancer (64).

These findings support the hypothesised role of SIRT1, FGFR2 and STAT3 as tumour promoters. However, an association between SIRT1, FGFR2 and STAT3 polymorphisms, and PA development, invasiveness, PA activity and recurrence has not yet been reported. The aim of the present study was to determine these associations.

\section{Materials and methods}

Patients and selection. Permission to undertake the present study was obtained from the Biomedical Research Ethics Committee of Lithuanian Health Sciences University (Kaunas, Lithuania). The study was conducted in the Departments of Ophthalmology and Neurosurgery, Lithuanian Health Sciences University Hospital (Kaunas, Lithuania).

The participants comprised of 143 patients with a diagnosis of PA. The reference group involved 808 healthy subjects. The reference group was created by taking into consideration the distribution of age and gender in the PA group. Therefore, the median patient age of the control group and the PA group did not differ significantly $(\mathrm{P}<0.05)$. Demographic data of the study subjects are presented in Table I.

The inclusion criteria were as follows: Determined and confirmed PA via magnetic resonance imaging (MRI); general good condition of the patient; consent of the patient to take part in the study; age $\geq 18$ years; and no other brain tumours or tumours with other localizations.

All PAs were analysed based on MRI findings. The pre-operative MRI investigations were performed with $1.5 \mathrm{~T}$ MRI scanners (Siemens MAGNETOM Avanto: Siemens AG, Munich, Germany; 1.5 T Philips ACHIEVA: Philips Healthcare, DA Best, The Netherlands) using a head coil and a standard pituitary scanning protocol, obtaining T1-weighted (T1W) sagittal and coronal and T2W/turbo spin echo coronal pre-contrast images, and T1W coronal and sagittal gadolinium-enhanced MR images with the intravenous agent gadodiamide (Omniscan; GE Healthcare Life Sciences, Chalfont, UK). The retrospective analysis of MRI data was conducted by an experienced radiologist. The suprasellar extension and sphenoid sinus invasion by PAs were classified according to Wilson-Hardy classification (Hardy classification, modified by Wilson) (19). The degree of suprasellar and parasellar extension was graded as stages A-E. The degree of sellar floor erosion was graded between I and IV. Grade III, localized sellar destruction, and grade IV, diffuse destruction, were considered to be invasive PAs. The Knosp classification system (4) was used to quantify invasion of the cavernous sinus,
Table I. Demographic characteristics of patients with PA and reference group subjects.

\begin{tabular}{lccc}
\hline Group & $\mathrm{n}$ & $\begin{array}{c}\text { Min/max/median } \\
\text { age, years }\end{array}$ & Females, n (\%) \\
\hline PA & 143 & $19 / 87 / 52.5$ & $88(65.67)$ \\
Control & 808 & $20 / 90 / 58$ & $510(63.12)$ \\
P-value & - & $0.793^{\mathrm{a}}$ & 0.882 \\
\hline
\end{tabular}

${ }^{\text {a }} \mathrm{P}$-value for comparison of the median age between the PA and control groups. PA, pituitary adenoma; min, minimum; max, maximum.

in which only grades 3 and 4 define true invasion of the tumour into the cavernous sinus: Grade 0 , no cavernous sinus involvement; grades 1 and 2, the tumour pushes into the medial wall of the cavernous sinus, but does not go beyond a hypothetical line extending between the centres of the two segments of the internal carotid artery (grade 1) or it goes beyond such a line, but without passing a line tangential to the lateral margins of the artery itself (grade 2); grade 3, the tumour extends laterally to the internal carotid artery within the cavernous sinus; and grade 4, total encasement of the intracavernous carotid artery.

DNA extraction and genotyping. The DNA extraction and analysis of the gene polymorphisms of SIRT1 rs12778366, FGFR2 rs2981582 and STAT3 rs744166 were performed at the Laboratory of Ophthalmology at the Institute of Neuroscience of the Lithuanian University of Health Sciences (Kaunas, Lithuania). DNA was extracted from $200 \mu 1$ venous blood (white blood cells) using a DNA purification kit based on the magnetic beads method (MagJET Genomic DNA kit; Thermo Fisher Scientific, Inc., Waltham, MA, USA) according to manufacturer's instructions.

The genotyping of SIRT1 rs12778366, FGFR2 rs2981582 and STAT3 rs 744166 was performed using the quantitative polymerase chain reaction (qPCR) method with a Rotor-Gene Q Real-Time PCR Quantification system (Qiagen, Inc., Valencia, CA, USA). All 3 single-nucleotide polymorphisms were determined using TaqMan ${ }^{\circledR}$ Genotyping assays (Applied Biosystems; Thermo Fisher Scientific, Inc.), C_1340370_10 (rs12778366), C_2917302_10 (rs2981582) and C_3140282_10 (rs744166), according to the manufacturer's protocols.

The Allelic Discrimination program (Applied Biosystems; Thermo Fisher Scientific, Inc.) was used during the qPCR. The assay was then continued following the manufacturer protocols. The Allelic Discrimination program was completed, and the genotyping results were received. The program determined the individual genotypes according to the fluorescence intensity rate from different detectors: Molecular marker labeled with VIC fluorescent dye was chosen for the $\mathrm{X}$ axis and a molecular marker labeled with FAM fluorescent dye was selected for the $\mathrm{Y}$ axis. These dy-labeled probes were included in the TaqMan ${ }^{\circledR}$ Genotyping assays.

Statistical analysis. Statistical analysis was performed using SPSS 20.0 software (IBM SPSS, Armonk, NY, USA). 
Table II. Frequency of single nucleotide polymorphisms in patients with PA and the control group.

\begin{tabular}{|c|c|c|c|c|c|c|}
\hline Gene marker & Control group, n (\%) & P-value HWE & PA group, n (\%) & P-value HWE & $\chi^{2}$ & P-value \\
\hline \multicolumn{7}{|c|}{ SIRT1 rs 12778366} \\
\hline \multicolumn{7}{|l|}{ Genotype } \\
\hline $\mathrm{T} / \mathrm{T}$ & $647(80.1)$ & $<0.01$ & $116(81.1)$ & $<0.001$ & 91.139 & $<0.001$ \\
\hline $\mathrm{T} / \mathrm{C}$ & $141(17.5)^{\mathrm{a}}$ & & $0(0.0)^{\mathrm{a}}$ & & & \\
\hline $\mathrm{C} / \mathrm{C}$ & $20(2.5)^{\mathrm{b}}$ & & $27(18.9)^{\mathrm{b}}$ & & & \\
\hline Total & $808(100.0)$ & & $143(100)$ & & & \\
\hline \multicolumn{7}{|l|}{ Allele } \\
\hline $\mathrm{T}$ & $1,435(88.8)$ & & $232(81.1)$ & & & \\
\hline $\mathrm{C}$ & $181(11.2)$ & & $54(18.9)$ & & & \\
\hline \multicolumn{7}{|c|}{ FGFR2 rs 2981582} \\
\hline \multicolumn{7}{|l|}{ Genotype } \\
\hline $\mathrm{G} / \mathrm{G}$ & $336(41.6)$ & $<0.001$ & $56(39.2)$ & $<0.001$ & 3.502 & 0.174 \\
\hline $\mathrm{G} / \mathrm{A}$ & $429(53.1)$ & & $84(58.7)$ & & & \\
\hline $\mathrm{A} / \mathrm{A}$ & $43(5.3)$ & & $3(2.1)$ & & & \\
\hline Total & $808(100.0)$ & & $143(100.0)$ & & & \\
\hline \multicolumn{7}{|l|}{ Allele } \\
\hline G & $1,101(68.1)$ & & $196(68.53)$ & & & \\
\hline A & $515(31.9)$ & & $90(31.47)$ & & & \\
\hline \multicolumn{7}{|c|}{ STAT3 rs 744166} \\
\hline \multicolumn{7}{|l|}{ Genotype } \\
\hline $\mathrm{G} / \mathrm{G}$ & $154(19.1)^{\mathrm{c}}$ & $<0.001$ & $13(9.1) \mathrm{c}$ & 0.354 & 8.825 & 0.012 \\
\hline $\mathrm{G} / \mathrm{A}$ & $363(44.9)$ & & $68(47.6)$ & & & \\
\hline $\mathrm{A} / \mathrm{A}$ & $291(36.0)$ & & $62(43.4)$ & & & \\
\hline Total & $808(100.0)$ & & $143(100.0)$ & & & \\
\hline \multicolumn{7}{|l|}{ Allele } \\
\hline G & $671(41.5)$ & & $94(32.9)$ & & & \\
\hline A & $945(58.5)$ & & $192(67.1)$ & & & \\
\hline
\end{tabular}

${ }^{\mathrm{a} S I R T 1}$ rs $1277836 \mathrm{~T} / \mathrm{C}$ genotype was significantly less frequent $(\mathrm{P}<0.001)$ in the PA group compared with the control group. ${ }^{\mathrm{b}}$ SIRT1 $r$ s 1277836 $\mathrm{C} / \mathrm{C}$ genotype was significantly more frequent $(\mathrm{P}<0.001)$ in the PA group compared with the control group. ${ }^{\mathrm{c}}$ STAT3 rs $744166 \mathrm{G} / \mathrm{G}$ genotype was significantly less frequent $(\mathrm{P}=0.003)$ in the $\mathrm{PA}$ group compared with the control group. PA, pituitary adenoma; SIRT1, sirtuin 1 , FGFR2, fibroblast growth factor receptor 2; STAT3, signal transducer and activator of transcription 3; HWE, Hardy-Weinberg equilibrium.

The data are presented as absolute numbers with percentages in brackets, and as median with minimum/maximum values. The frequencies of genotypes are presented as percentages.

Hardy-Weinberg analysis was performed to compare the observed and expected frequencies of rs12778366, rs2981582 and rs744166 using the $\chi^{2}$ test in all groups. The distribution of rs12778366, rs2981582 and rs744166 single-nucleotide polymorphisms (SNPs) in the PA and control groups was compared using the $\chi^{2}$ test or Fisher's exact test. Binomial logistic regression analysis was performed to estimate the impact of genotypes on PA development. Odds ratios (ORs) and 95\% confidence intervals (CIs) are presented. Only statistically significant variables are presented in the tables. The selection of the most suitable genetic model was based on the Akaike Information Criterion (AIC), whereby the best genetic models were those with the lowest AIC values (65). $\mathrm{P}<0.05$ was considered to indicate a statistically significant difference.

\section{Results}

Genotype distribution in the PA patients and the control group. The genotyping of SIRT1 rs12778366, FGFR2 rs2981582 and STAT3 rs744166 was performed in the PA group and the control group subjects (Table II).

The distribution of analysed SIRT1 genotypes and allele frequencies in the control and PA groups did not match the Hardy-Weinberg equilibrium. The SIRT1 rs12778366 polymorphism analysis in the overall group revealed differences in the genotype distribution between patients with PA and control group subjects $(\mathrm{P}<0.001)$. The genotype $\mathrm{T} / \mathrm{C}$ was significantly less frequent in the PA group compared with the healthy controls ( 0 vs. $17.5 \%$; $\mathrm{P}<0.001$ ) and the genotype $\mathrm{C} / \mathrm{C}$ was significantly more frequent in the PA group compared with the healthy control group (18.9 vs. $2.5 \%$, respectively; $\mathrm{P}<0.001$ ) (Table II).

The distribution of analysed FGFR2 genotypes and allele frequencies in the control and PA groups did not match the 
Table III. Frequency of single nucleotide polymorphisms in patients with PA and control group according to gender.

\begin{tabular}{|c|c|c|c|c|c|c|c|c|}
\hline \multirow[b]{2}{*}{ Gene marker } & \multicolumn{4}{|c|}{ Control group, $\mathrm{n}(\%)$} & \multicolumn{4}{|c|}{ PA group, n (\%) } \\
\hline & Females & Males & $\begin{array}{c}\text { P-value } \\
\text { HWE }\end{array}$ & P-value & Females & Males & $\begin{array}{c}\text { P-value } \\
\text { HWE }\end{array}$ & P-value \\
\hline \multicolumn{9}{|c|}{ SIRT1 rs 12778366} \\
\hline \multicolumn{9}{|l|}{ Genotype } \\
\hline $\mathrm{T} / \mathrm{T}$ & 407 (79.8) & $240(80.5)$ & 0.811 & 0.801 & $71(80.7)$ & $45(81.8)$ & 0.866 & 0.866 \\
\hline $\mathrm{T} / \mathrm{C}$ & $89(17.5)^{\mathrm{a}}$ & $52(17.4)^{\mathrm{b}}$ & & 1.000 & $0(0.0)^{\mathrm{a}}$ & $0(0.0)^{\mathrm{b}}$ & & 1.00 \\
\hline $\mathrm{C} / \mathrm{C}$ & $14(2.7)^{\mathrm{c}}$ & $6(2.0)^{\mathrm{d}}$ & & 0.518 & $17(19.3)^{\mathrm{c}}$ & $10(18.2)^{\mathrm{d}}$ & & 0.866 \\
\hline Total & $510(100.0)$ & $298(100.0)$ & & & $88(100.0)$ & $55(100.0)$ & & \\
\hline \multicolumn{9}{|l|}{ Allele } \\
\hline $\mathrm{T}$ & $903(88.5)$ & $532(89.3)$ & & & $142(80.7)$ & $90(81.8)$ & & \\
\hline $\mathrm{C}$ & $117(11.5)$ & $64(10.7)$ & & & $34(19.3)$ & $20(18.2)$ & & \\
\hline \multicolumn{9}{|c|}{ FGFR2 rs 2981582} \\
\hline \multicolumn{9}{|l|}{ Genotype } \\
\hline $\mathrm{G} / \mathrm{G}$ & $218(42.7)$ & $118(39.6)$ & 0.675 & 0.381 & $39(44.3)$ & $17(30.9)$ & 0.197 & 0.117 \\
\hline $\mathrm{G} / \mathrm{A}$ & $265(52.0)$ & $164(55.0)$ & & 0.398 & $48(54.5)$ & $36(65.5)$ & & 0.224 \\
\hline $\mathrm{A} / \mathrm{A}$ & $27(5.3)$ & $16(5.4)$ & & 1.0 & $1(1.1)$ & $2(3.6)$ & & 0.559 \\
\hline Total & $510(100)$ & $298(100)$ & & & $88(100)$ & $55(100)$ & & \\
\hline \multicolumn{9}{|l|}{ Allele } \\
\hline G & $701(68.7)$ & $400(67.1)$ & & & $126(71.6)$ & $70(63.6)$ & & \\
\hline A & $319(31.3)$ & $196(32.9)$ & & & $50(28.4)$ & $40(36.4)$ & & \\
\hline \multicolumn{9}{|c|}{ STAT3 rs 744166} \\
\hline \multicolumn{9}{|l|}{ Genotype } \\
\hline $\mathrm{G} / \mathrm{G}$ & $104(20.4)^{\mathrm{e}}$ & $50(16.8)$ & 0.378 & 0.207 & $7(8.0)^{\mathrm{e}}$ & $6(10.9)$ & 0.815 & 0.563 \\
\hline $\mathrm{G} / \mathrm{A}$ & $229(44.9)$ & $134(45.0)$ & & 0.986 & $43(48.9)$ & $25(45.5)$ & & 0.733 \\
\hline $\mathrm{A} / \mathrm{A}$ & $177(34.7)$ & $114(38.3)$ & & 0.312 & $38(43.2)$ & $24(43.6)$ & & 1.00 \\
\hline Total & $510(100)$ & $298(100)$ & & & $88(100)$ & $55(100)$ & & \\
\hline \multicolumn{9}{|l|}{ Allele } \\
\hline $\mathrm{G}$ & $437(42.84)$ & $234(39.3)$ & & & $57(32.4)$ & $37(33.6)$ & & \\
\hline A & $583(57.2)$ & $362(60.7)$ & & & $119(67.6)$ & $73(66.4)$ & & \\
\hline
\end{tabular}

${ }^{\mathrm{a} S I R T 1}$ rs $12778366 \mathrm{~T} / \mathrm{C}$ genotype is significantly less frequent $(\mathrm{P}<0.001)$ in PA females compared with control females. ${ }^{\mathrm{b}}$ SIRT1 rs 12778366 $\mathrm{T} / \mathrm{C}$ genotype is significantly less frequent $(\mathrm{P}<0.001)$ in PA males compared with control males. ${ }^{\mathrm{c}}$ SIRT1 rs $12778366 \mathrm{C} / \mathrm{C}$ genotype is significantly more frequent $(\mathrm{P}<0.001)$ in $\mathrm{PA}$ females compared with control females. ${ }^{\mathrm{d} S I R T 1} \mathrm{r}$ s $12778366 \mathrm{C} / \mathrm{C}$ genotype is significantly more frequent $(\mathrm{P}<0.001)$ in PA males compared with control males. ${ }^{\mathrm{e}}$ STAT3 $r s 744166 \mathrm{G} / \mathrm{G}$ genotype is significantly less frequent $(\mathrm{P}=0.004)$ in $\mathrm{PA}$ females compared with control females. PA, pituitary adenoma; SIRT1, sirtuin 1; FGFR2, fibroblast growth factor receptor 2; STAT3, signal transducer and activator of transcription 3; HWE, Hardy-Weinberg equilibrium.

Hardy-Weinberg equilibrium. Statistical analysis did not reveal significant genotype (G/G, G/A and A/A) distribution differences between the control and PA groups: 41.6 vs. $39.2 \%, 53.1$ vs. $58.7 \%$, and 5.3 vs. $2.1 \%$, respectively $(\mathrm{P}=0.174)$ (Table II).

The distribution of the analysed STAT3 rs 744166 genotypes and allele frequencies did not match the Hardy-Weinberg equilibrium in the control group, but it did in the group of patients with PA. STAT3 rs744166 polymorphism analysis in the overall group revealed differences in the genotype distribution between the patients with PA and the control group $(\mathrm{P}=0.012)$. The genotype G/G was less frequent in the PA group compared with the healthy controls ( 9.1 vs. $19.1 \%$, respectively; $\mathrm{P}=0.003$ ) (Table II).
Genotype distribution in the PA patients and the control group by gender. All 3 SNPs were analysed in the PA and control groups according to gender (Table III). SIRT1 rs12778366 polymorphism analysis did not revealed any statistically significant differences between females and males with PA in genotype (T/T, T/C and C/C) distribution (80.7, 0 and 19.3\% vs. $81.8,0$ and $18.2 \%$, respectively; Table III). Comparing SIRT1 rs12778366 genotype distribution in healthy females and females with PA, significant differences were revealed. The T/C genotype was less frequently present in females with PA compared with the healthy control females $(0$ vs. $17.5 \%$, respectively; $\mathrm{P}<0.001)$ and $\mathrm{C} / \mathrm{C}$ was more frequent in PA females compared with healthy females (19.3 vs. $2.7 \%$, 
Table IV. Binomial logistic regression analysis in patients with pituitary adenoma and the control group.

\begin{tabular}{|c|c|c|c|c|c|}
\hline Gene & Model & Genotype & OR $(95 \% \mathrm{CI})$ & P-value & AIC \\
\hline \multirow[t]{6}{*}{ SIRT1 rs 12778366} & Co-dominant & $\mathrm{T} / \mathrm{T}$ & 1.000 & & 720.516 \\
\hline & & $\mathrm{T} / \mathrm{C}$ & $0(0.000)$ & 0.995 & \\
\hline & & $\mathrm{C} / \mathrm{C}$ & $7.530(4.087-13.873)$ & $<0.001$ & \\
\hline & Recessive & $\mathrm{T} / \mathrm{T}+\mathrm{T} / \mathrm{C}$ & 1.000 & & 780.895 \\
\hline & & $\mathrm{C} / \mathrm{C}$ & $9.171(4.982-16.881)$ & $<0.001$ & \\
\hline & Additive & - & $1.584(1.187-2.115)$ & 0.002 & 780.214 \\
\hline \multirow[t]{6}{*}{ STAT3 rs 744166} & Co-dominant & $\mathrm{A} / \mathrm{A}$ & 1.000 & & 801.223 \\
\hline & & $\mathrm{G} / \mathrm{G}$ & $0.879(0.603-1.282)$ & 0.504 & \\
\hline & & $\mathrm{G} / \mathrm{G}$ & $0.396(0.211-0.743)$ & 0.004 & \\
\hline & Recessive & $\mathrm{A} / \mathrm{A}+\mathrm{G} / \mathrm{A}$ & 1.000 & & 799.670 \\
\hline & & $\mathrm{G} / \mathrm{G}$ & $0.425(0.234-0.771)$ & 0.005 & \\
\hline & Additive & - & $0.702(0.541-0.911)$ & 0.008 & 801.881 \\
\hline
\end{tabular}

OR, odds ratio; CI, confidence interval; AIC, Akaike Information Criterion; SIRT1, sirtuin 1; STAT3, signal transducer and activator of transcription 3 .

Table V. Binomial logistic regression analysis in patients with pituitary adenoma and control subjects according to gender.

\begin{tabular}{|c|c|c|c|c|c|c|}
\hline Gene & Gender & Model & Genotype & OR $(95 \% \mathrm{CI})$ & P-value & AIC \\
\hline \multirow[t]{11}{*}{ SIRT1 rs 12778366} & \multirow[t]{5}{*}{ Male } & \multirow[t]{3}{*}{ Co-dominant } & $\mathrm{T} / \mathrm{T}$ & 1.000 & & 275.783 \\
\hline & & & $\mathrm{T} / \mathrm{C}$ & $0.000(0.000)$ & 0.997 & \\
\hline & & & $\mathrm{C} / \mathrm{C}$ & $8.889(3.076-25.683)$ & $<0.001$ & \\
\hline & & \multirow[t]{2}{*}{ Recessive } & $\mathrm{T} / \mathrm{T}+\mathrm{T} / \mathrm{C}$ & 1.000 & & 290.082 \\
\hline & & & $\mathrm{C} / \mathrm{C}$ & $10.815(3.748-31.205)$ & $<0.001$ & \\
\hline & \multirow[t]{6}{*}{ Female } & \multirow[t]{3}{*}{ Co-dominant } & $\mathrm{T} / \mathrm{T}$ & 1.000 & & 450.358 \\
\hline & & & $\mathrm{T} / \mathrm{C}$ & $0.000(0.000)$ & 0.996 & \\
\hline & & & $\mathrm{C} / \mathrm{C}$ & $6.961(3.285-14.750)$ & $<0.001$ & \\
\hline & & \multirow[t]{2}{*}{ Recessive } & $\mathrm{T} / \mathrm{T}+\mathrm{T} / \mathrm{C}$ & 1.000 & & 474.428 \\
\hline & & & $\mathrm{C} / \mathrm{C}$ & $8.483(4.008-17.955)$ & $<0.001$ & \\
\hline & & Additive & - & $1.580(1.100-2.271)$ & 0.013 & 497.979 \\
\hline \multirow[t]{6}{*}{ STAT3 rs 744166} & \multirow[t]{6}{*}{ Female } & \multirow[t]{3}{*}{ Co-dominant } & $\mathrm{A} / \mathrm{A}$ & 1.000 & & 496.249 \\
\hline & & & $\mathrm{G} / \mathrm{A}$ & $0.875(0.542-1.411)$ & 0.583 & \\
\hline & & & $\mathrm{G} / \mathrm{G}$ & $0.314(0.135-0.727)$ & 0.007 & \\
\hline & & \multirow[t]{2}{*}{ Recessive } & $\mathrm{A} / \mathrm{A}+\mathrm{G} / \mathrm{A}$ & 1.000 & & 494.549 \\
\hline & & & $\mathrm{G} / \mathrm{G}$ & $0.337(0.151-0.752)$ & 0.008 & \\
\hline & & Additive & - & $0.654(0.469-0.912)$ & 0.012 & 497.077 \\
\hline
\end{tabular}

OR, odds ratio; CI, confidence interval; AIC, Akaike Information Criterion; SIRT1, sirtuin 1; STAT3, signal transducer and activator of transcription 3 .

respectively; $\mathrm{P}<0.001)$. The $\mathrm{T} / \mathrm{T}$ genotype did not exhibit any significant differences when healthy females and females with PA were compared. When analysing genotype distribution in males, T/C genotype distribution showed statistically significant difference between males with PA and healthy males $(0$ vs. $17.4 \%$, respectively; $\mathrm{P}<0.001)$ and the $\mathrm{C} / \mathrm{C}$ genotype was more frequent in males with PA compared with the control group (18.2 vs. $2.0 \%$, respectively; $\mathrm{P}<0.001)$ (Table III).
FGFR2 rs2981582 polymorphism analysis by gender was performed, but it did not reveal any genotype distribution differences between females and males.

STAT3 rs744166 polymorphism analysis did not reveal any significant differences between females and males with PA in the genotype $(\mathrm{G} / \mathrm{G}, \mathrm{G} / \mathrm{A}$ and $\mathrm{A} / \mathrm{A})$ distribution $(8.0,48.9$ and $43.2 \%$ vs. $10.9,45.5$ and $43.6 \%$, respectively; Table III) either. When comparing STAT3 genotype distribution between healthy 
Table VI. Frequency of SNPs in patients with PA and in control group according to PA invasiveness.

\begin{tabular}{|c|c|c|c|c|c|c|}
\hline Gene marker & $\begin{array}{c}\text { Control } \\
\text { group, n }(\%)\end{array}$ & $\begin{array}{l}\text { P-value } \\
\text { HWE }\end{array}$ & $\begin{array}{c}\text { Non invasive } \\
\text { PA group, n }(\%)\end{array}$ & $\begin{array}{l}\text { P-value } \\
\text { HWE }\end{array}$ & $\begin{array}{l}\text { Invasive PA } \\
\text { group, n (\%) }\end{array}$ & $\begin{array}{c}\text { P-value } \\
\text { HWE }\end{array}$ \\
\hline \multicolumn{7}{|c|}{ SIRT1 rs 12778366} \\
\hline \multicolumn{7}{|l|}{ Genotype } \\
\hline $\mathrm{T} / \mathrm{T}$ & $647(80.1)$ & \multirow{4}{*}{$<0.001$} & $47(81.0)$ & \multirow[t]{4}{*}{$<0.001$} & $69(81.2)$ & \multirow[t]{4}{*}{$<0.001$} \\
\hline $\mathrm{T} / \mathrm{C}$ & $141(17.5)^{\mathrm{a}, \mathrm{b}}$ & & $0(0.0)^{\mathrm{a}}$ & & $0(0.0)^{\mathrm{b}}$ & \\
\hline $\mathrm{C} / \mathrm{C}$ & $20(2.5)^{\mathrm{c}, \mathrm{d}}$ & & $11(19.0)^{\mathrm{c}}$ & & $16(18.8)^{\mathrm{d}}$ & \\
\hline Total & $808(100.0)$ & & $58(100.0)$ & & $85(100.0)$ & \\
\hline \multicolumn{7}{|l|}{ Allele } \\
\hline $\mathrm{T}$ & $1,435(88.8)$ & & $94(81.0)$ & & $138(81.2)$ & \\
\hline $\mathrm{C}$ & $181(11.2)$ & & $22(19.0)$ & & $32(18.8)$ & \\
\hline \multicolumn{7}{|c|}{ FGFR2 rs2981582 } \\
\hline \multicolumn{7}{|l|}{ Genotype } \\
\hline $\mathrm{G} / \mathrm{G}$ & $336(41.6)^{\mathrm{e}}$ & \multirow[t]{4}{*}{$<0.001$} & $16(27.6)^{\mathrm{e}, \mathrm{f}}$ & \multirow[t]{4}{*}{$<0.001$} & $40(47.1)^{\mathrm{f}}$ & \multirow[t]{4}{*}{0.043} \\
\hline $\mathrm{G} / \mathrm{A}$ & $429(53.1)^{\mathrm{g}}$ & & $42(72.4)^{\mathrm{g}, \mathrm{h}}$ & & $42(49.4)^{\mathrm{h}}$ & \\
\hline $\mathrm{A} / \mathrm{A}$ & $43(5.3)$ & & $0(0.0)$ & & $3(3.5)$ & \\
\hline Total & $808(100.0)$ & & $58(100.0)$ & & $85(100.0)$ & \\
\hline \multicolumn{7}{|l|}{ Allele } \\
\hline $\mathrm{G}$ & $1,101(68.1)$ & & $74(63.8)$ & & $122(71.8)$ & \\
\hline A & $515(31.9)$ & & $42(36.2)$ & & $48(28.2)$ & \\
\hline \multicolumn{7}{|c|}{ STAT3 rs 744166} \\
\hline \multicolumn{7}{|l|}{ Genotype } \\
\hline $\mathrm{G} / \mathrm{G}$ & $154(19.1)^{\mathrm{i}}$ & \multirow[t]{4}{*}{$<0.001$} & $9(15.5)^{\mathrm{j}}$ & \multirow[t]{4}{*}{0.313} & $4(4.7)^{\mathrm{i}, \mathrm{j}}$ & \multirow[t]{4}{*}{0.031} \\
\hline $\mathrm{G} / \mathrm{A}$ & $363(44.9)$ & & $23(39.7)$ & & $45(52.9)$ & \\
\hline $\mathrm{A} / \mathrm{A}$ & $291(36.0)$ & & $26(44.8)$ & & $36(42.4)$ & \\
\hline Total & $808(100.0)$ & & $58(100.0)$ & & $85(100.0)$ & \\
\hline \multicolumn{7}{|l|}{ Allele } \\
\hline G & $671(41.5)$ & & $41(35.3)$ & & $53(31.2)$ & \\
\hline A & $945(58.5)$ & & $75(64.7)$ & & $117(68.8)$ & \\
\hline
\end{tabular}

${ }^{\mathrm{a}}$ SIRT1 rs $12778366 \mathrm{~T} / \mathrm{C}$ genotype is significantly less frequent $(\mathrm{P}=0.021)$ in non-invasive PA compared with the control group. ${ }^{\mathrm{b}} \mathrm{SIRT1}$ rs $12778366 \mathrm{~T} / \mathrm{C}$ genotype is significantly less frequent $(\mathrm{P}<0.001)$ in invasive $\mathrm{PA}$ compared with the control group. ${ }^{\mathrm{c}}$ SIRT1 rs $12778366 \mathrm{C} / \mathrm{C}$ genotype is significantly more frequent $(\mathrm{P}=0.041)$ in non-invasive $\mathrm{PA}$ compared with the control group. ${ }^{\mathrm{d}}$ SIRT1 rs $12778366 \mathrm{C} / \mathrm{C}$ genotype is significantly less frequent $(\mathrm{P}<0.001)$ in invasive PA compared with the control group. ${ }^{\mathrm{e}} F G F R 2$ rs $2981582 \mathrm{G} / \mathrm{G}$ genotype is significantly less frequent $(\mathrm{P}=0.038)$ in non-invasive PA compared with the control group. ${ }^{\mathrm{f}} F G F R 2$ rs $2981582 \mathrm{G} / \mathrm{G}$ genotype is significantly more frequent $(\mathrm{P}=0.024)$ in invasive PA compared with the non-invasive PA group. ${ }^{g} F G F R 2$ rs $2981582 \mathrm{G} / \mathrm{A}$ genotype is significantly more frequent $(\mathrm{P}=0.004)$ in non-invasive PA compared with the control group. ${ }^{\mathrm{h}} F G F R 2$ rs $2981582 \mathrm{G} / \mathrm{A}$ genotype is significantly less frequent $(\mathrm{P}=0.009)$ in invasive $\mathrm{PA}$ compared with the non-invasive PA group. iSTAT3 rs744166 G/G genotype is significantly less frequent $(\mathrm{P}<0.001)$ in invasive PA compared with the control group. ${ }^{\mathrm{j} S T A T 3}$ rs $744166 \mathrm{G} / \mathrm{G}$ genotype is significantly less frequent $(\mathrm{P}=0.038)$ in invasive PA compared with the non-invasive PA group. PA, pituitary adenoma; SIRT1, sirtuin 1, FGFR2, fibroblast growth factor receptor 2; STAT3, signal transducer and activator of transcription 3; HWE, Hardy-Weinberg equilibrium.

females and females with PA, there were significant differences. The STAT3 rs $744166 \mathrm{G} / \mathrm{G}$ genotype was less frequently present in PA females compared with healthy control females (8.0 vs. $20.4 \%$, respectively; $\mathrm{P}=0.004)$. The STAT3 rs $744166 \mathrm{G} / \mathrm{A}$ and A/A genotype distribution did not exhibit any significant differences when healthy females and females with PA were compared. STAT3 rs744166 analysis between male groups did not reveal any statistically significant differences (Table III).

Binomial logistic regression analysis of the patients with PA and the control group. Binomial logistic regression analysis of the patients with PA and the control group was performed (Table IV). SIRT1 rs 12778366 analysis revealed that there were significant variables in the co-dominant $(\mathrm{OR}=7.530 ; 95 \% \mathrm{CI}$ : 4.087-13.873; $\mathrm{P}<0.001$ ), recessive (OR=9.171; 95\% CI: 4.982-16.881; $\mathrm{P}<0.001)$ and additive (OR=1.584: $95 \% \mathrm{CI}$ : 1.187-2.115; $\mathrm{P}=0.002)$ models of the patients with PA and the control group (Table IV).

FGFR2 rs2981582 analysis did not reveal any significant variables.

STAT3 rs744166 analysis revealed that there were significant variables in the co-dominant $(\mathrm{OR}=0.396 ; 95 \%$ CI: 0.211-0.743; $\mathrm{P}=0.004)$, recessive $(\mathrm{OR}=0.425 ; 95 \% \mathrm{CI}$ : 
Table VII. Frequency of single nucleotide polymorphisms in patients with PA and in the control group according to PA recurrences.

\begin{tabular}{|c|c|c|c|c|c|c|}
\hline Gene marker & $\begin{array}{c}\text { Control } \\
\text { group, n }(\%)\end{array}$ & $\begin{array}{l}\text { P-value } \\
\text { HWE }\end{array}$ & $\begin{array}{l}\text { Non-recurrent } \\
\text { PA group, n }(\%)\end{array}$ & $\begin{array}{l}\text { P-value } \\
\text { HWE }\end{array}$ & $\begin{array}{l}\text { Recurrent PA } \\
\text { group, n (\%) }\end{array}$ & $\begin{array}{l}\text { P-value } \\
\text { HWE }\end{array}$ \\
\hline \multicolumn{7}{|c|}{ SIRT1 rs 12778366} \\
\hline \multicolumn{7}{|l|}{ Genotype } \\
\hline $\mathrm{T} / \mathrm{T}$ & $647(80.1)$ & $<0.001$ & $91(81.3)$ & $<0.001$ & $25(80.6)$ & $<0.001$ \\
\hline $\mathrm{T} / \mathrm{C}$ & $141(17.5)^{\mathrm{a}, \mathrm{b}}$ & & $0(0.0)^{\mathrm{a}}$ & & $0(0.0)^{\mathrm{b}}$ & \\
\hline $\mathrm{C} / \mathrm{C}$ & $20(2.5)^{\mathrm{c}, \mathrm{d}}$ & & $21(18.8)^{\mathrm{c}}$ & & $6(19.4)^{\mathrm{d}}$ & \\
\hline Total & $808(100)$ & & $112(100.0)$ & & $31(100.0)$ & \\
\hline \multicolumn{7}{|l|}{ Allele } \\
\hline $\mathrm{T}$ & $1,435(88.8)$ & & $182(81.3)$ & & $50(80.6)$ & \\
\hline $\mathrm{C}$ & $181(11.2)$ & & $42(18.8)$ & & $12(19.4)$ & \\
\hline \multicolumn{7}{|c|}{ FGFR2 rs 2981582} \\
\hline \multicolumn{7}{|l|}{ Genotype } \\
\hline $\mathrm{G} / \mathrm{G}$ & 336 (41.6) & $<0.001$ & $44(39.3)$ & $<0.001$ & $12(38.7)$ & 0.067 \\
\hline $\mathrm{G} / \mathrm{A}$ & $429(53.1)$ & & $66(58.9)$ & & $18(58.1)$ & \\
\hline $\mathrm{A} / \mathrm{A}$ & $43(5.3)$ & & $2(1.8)$ & & $1(3.2)$ & \\
\hline Total & $808(100.0)$ & & $112(100.0)$ & & $31(100.0)$ & \\
\hline \multicolumn{7}{|l|}{ Allele } \\
\hline $\mathrm{G}$ & $1,101(68.1)$ & & $154(68.8)$ & & $42(67.7)$ & \\
\hline A & 515 (31.9) & & $70(31.3)$ & & $20(32.3)$ & \\
\hline \multicolumn{7}{|c|}{ STAT3 rs 744166} \\
\hline \multicolumn{7}{|l|}{ Genotype } \\
\hline $\mathrm{G} / \mathrm{G}$ & $154(19.1)^{\mathrm{e}}$ & $<0.001$ & $7(6.3)^{\mathrm{e}, \mathrm{f}}$ & 0.083 & $6(19.4)^{\mathrm{f}}$ & 0.305 \\
\hline $\mathrm{G} / \mathrm{A}$ & 363 (44.9) & & $56(50.0)$ & & $12(38.7)$ & \\
\hline $\mathrm{A} / \mathrm{A}$ & $291(36.0)$ & & $49(43.8)$ & & $13(41.9)$ & \\
\hline Total & $808(100.0)$ & & $112(100.0)$ & & $31(100.0)$ & \\
\hline \multicolumn{7}{|l|}{ Allele } \\
\hline $\mathrm{G}$ & $671(41.5)$ & & $70(31.3)$ & & $24(38.7)$ & \\
\hline A & $945(58.5)$ & & $154(68.8)$ & & $38(61.3)$ & \\
\hline
\end{tabular}

${ }^{\mathrm{a} S I R T 1}$ rs $12778366 \mathrm{~T} / \mathrm{C}$ genotype is significantly less frequent $(\mathrm{P}<0.001)$ in non-recurrent PA compared with the control group. ${ }^{\mathrm{b}} \mathrm{SIRT1}$ $r s 12778366 \mathrm{~T} / \mathrm{C}$ genotype is significantly less frequent $\left({ }^{\mathrm{b}} \mathrm{P}=0.005\right)$ in recurrent PA compared with the control group. ${ }^{\mathrm{c}} \mathrm{SIRT1}$ rs $12778366 \mathrm{C} / \mathrm{C}$ genotype is significantly more frequent $(\mathrm{P}<0.001)$ in non-recurrent $\mathrm{PA}$ compared with the control group. ${ }^{\mathrm{d}}$ SIRT1 rs $12778366 \mathrm{C} / \mathrm{C}$ genotype is significantly more frequent $(\mathrm{P}=0.047)$ in recurrent $\mathrm{PA}$ compared with the control group. ${ }^{\mathrm{e}}$ STAT3 $r$ s $744166 \mathrm{G} / \mathrm{G}$ genotype is significantly less frequent $(\mathrm{P}<0.001)$ in non-recurrent PA compared with the control group. ${ }^{\mathrm{f}} F G F R 2 \mathrm{rs} 2981582 \mathrm{G} / \mathrm{G}$ genotype is statistically more frequent $(\mathrm{P}=0.036)$ in recurrent PA compared with non-recurrent PA.PA, pituitary adenoma; SIRT1, sirtuin 1, FGFR2, fibroblast growth factor receptor 2; STAT3, signal transducer and activator of transcription 3; HWE, Hardy-Weinberg equilibrium.

$0.234-0.771 ; \mathrm{P}=0.005)$ and additive $(\mathrm{OR}=0.702 ; 95 \% \mathrm{CI}$ : $0.541-0.911 ; \mathrm{P}=0.008)$ models of the patients with $\mathrm{PA}$ and the control group (Table IV).

Binomial logistic regression analysis in the patients with PA and the control group according to gender was performed (Table V). In the SIRT1 rs 12778366 analysis there were statistically significant variables in the co-dominant $(\mathrm{P}<0.001)$ and recessive $(\mathrm{P}<0.001)$ models of males. The co-dominant $(\mathrm{P}<0.001)$, recessive $(\mathrm{P}<0.001)$ and additive $(\mathrm{P}=0.013)$ variables were also significant in females.

Binomial logistic regression analysis of FGFR2 rs2981582 in the patients with PA and in the control group according to gender was performed, but no significant variables were observed.

However, binomial logistic regression analysis of STAT3 $r s 744166$ in the patients with PA and in the control group according to gender showed statistically significant variables only in the co-dominant $(\mathrm{P}=0.007)$, recessive $(\mathrm{P}=0.008)$ and additive $(\mathrm{P}=0.012)$ models of females (Table $\mathrm{V})$.

Genotype distribution in the control group and the PA patients by different PA subgroups. Analysis of SIRT1 rs1277836, FGFR2 rs2981582 and STAT3 rs744166 polymorphisms was performed by different PA subgroups (Tables VI-VIII).

The SIRT1 rs12778366 T/C genotype was less frequently observed in non-invasive, non-recurrent and inactive PA subgroups compared with healthy controls (0 vs. 17.5\%, $\mathrm{P}=0.021 ; 0$ vs. $17.5 \%, \mathrm{P}<0.001 ; 0$ vs. $17.5 \%, \mathrm{P}<0.001$, respectively). However, no differences were observed between non-invasive and invasive, non-recurrent and recurrent, and inactive and active PA subgroups (Tables VI-VIII). 
Table VIII. Frequency of single nucleotide polymorphisms in patients with PA and in the control group according to PA activity.

\begin{tabular}{|c|c|c|c|c|c|c|}
\hline Gene marker & $\begin{array}{c}\text { Control } \\
\text { group,n }(\%)\end{array}$ & $\begin{array}{l}\text { P-value } \\
\text { HWE }\end{array}$ & $\begin{array}{c}\text { Inactive } \\
\text { PA group, n (\%) }\end{array}$ & $\begin{array}{l}\text { P-value } \\
\text { HWE }\end{array}$ & $\begin{array}{c}\text { Active PA } \\
\text { group, n (\%) }\end{array}$ & $\begin{array}{l}\text { P-value } \\
\text { HWE }\end{array}$ \\
\hline \multicolumn{7}{|c|}{ SIRT1 rs 12778366} \\
\hline \multicolumn{7}{|l|}{ Genotype } \\
\hline $\mathrm{T} / \mathrm{T}$ & $647(80.1)$ & \multirow[t]{4}{*}{$<0.001$} & $48(76.2)$ & \multirow[t]{4}{*}{0.007} & $68(85.0)$ & \multirow[t]{4}{*}{0.044} \\
\hline $\mathrm{T} / \mathrm{C}$ & $141(17.5)^{\mathrm{a}, \mathrm{b}}$ & & $0(0.0)^{\mathrm{a}}$ & & $0(0.0)^{\mathrm{b}}$ & \\
\hline $\mathrm{C} / \mathrm{C}$ & $20(2.5)^{\mathrm{c}, \mathrm{d}}$ & & $15(23.8)^{\mathrm{d}}$ & & $12(15.0)^{\mathrm{c}}$ & \\
\hline Total & $808(100.0)$ & & $63(100.0)$ & & $80(100.0)$ & \\
\hline \multicolumn{7}{|l|}{ Allele } \\
\hline $\mathrm{T}$ & $1,435(88.8)$ & & $96(76.2)$ & & $136(85.0)$ & \\
\hline $\mathrm{C}$ & $181(11.2)$ & & $30(23.8)$ & & $24(15.0)$ & \\
\hline \multicolumn{7}{|c|}{ FGFR2 rs 2981582} \\
\hline \multicolumn{7}{|l|}{ Genotype } \\
\hline $\mathrm{G} / \mathrm{G}$ & $336(41.6)$ & \multirow[t]{4}{*}{$<0.001$} & $25(39.7)$ & \multirow[t]{4}{*}{$<0.001$} & $31(38.8)$ & \multirow[t]{4}{*}{0.005} \\
\hline $\mathrm{G} / \mathrm{A}$ & $429(53.1)$ & & $38(60.3)$ & & $46(57.5)$ & \\
\hline $\mathrm{A} / \mathrm{A}$ & $43(5.3)$ & & $0(0.0)$ & & $3(3.8)$ & \\
\hline Total & $808(100.0)$ & & $63(100.0)$ & & $80(100.0)$ & \\
\hline \multicolumn{7}{|l|}{ Allele } \\
\hline G & $1,101(68.1)$ & & $88(69.8)$ & & $108(67.5)$ & \\
\hline A & $515(31.9)$ & & $38(30.2)$ & & $52(32.5)$ & \\
\hline \multicolumn{7}{|c|}{ STAT3 rs744166 } \\
\hline \multicolumn{7}{|l|}{ Genotype } \\
\hline $\mathrm{G} / \mathrm{G}$ & $154(19.1)^{\mathrm{e}}$ & \multirow[t]{4}{*}{$<0.001$} & $6(9.5)$ & \multirow[t]{4}{*}{0.193} & $7(8.8)^{\mathrm{e}}$ & \multirow[t]{4}{*}{0.915} \\
\hline $\mathrm{G} / \mathrm{A}$ & 363 (44.9) & & $34(54.0)$ & & $34(42.5)$ & \\
\hline $\mathrm{A} / \mathrm{A}$ & $291(36.0)^{\mathrm{f}}$ & & $23(36.5)$ & & $39(48.8)^{\mathrm{f}}$ & \\
\hline Total & $808(100.0)$ & & $63(100.0)$ & & $80(100.0)$ & \\
\hline \multicolumn{7}{|l|}{ Allele } \\
\hline G & $671(41.5)$ & & $46(36.5)$ & & $48(30.0)$ & \\
\hline A & $945(58.5)$ & & $80(63.5)$ & & $112(70.0)$ & \\
\hline
\end{tabular}

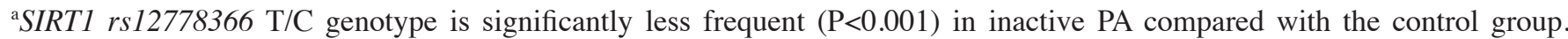
${ }^{\mathrm{b}}$ SIRT1 rs $12778366 \mathrm{~T} / \mathrm{C}$ genotype is significantly less frequent $(\mathrm{P}<0.001)$ in active PA compared with the control group. ${ }^{\mathrm{c}}$ SIRT1 $r s 12778366 \mathrm{C} / \mathrm{C}$ genotype is significantly less frequent $(\mathrm{P}<0.001)$ in active PA compared with the control group. ${ }^{d}$ SIRT1 $r s 12778366 \mathrm{C} / \mathrm{C}$ genotype is significantly more frequent $(\mathrm{P}<0.001)$ in inactive PA compared with the control group. ${ }^{e} F G F R 2$ $r s 2981582 \mathrm{G} / \mathrm{G}$ genotype is significantly less frequent $(\mathrm{P}=0.022)$ in active PA compared with the control group. ${ }^{\mathrm{f}} F G F R 2$ rs2981582 A/A genotype is significantly more frequent $(\mathrm{P}=0.029)$ in active PA compared with the control group. PA, pituitary adenoma; SIRT1, sirtuin 1, FGFR2, fibroblast growth factor receptor 2; STAT3, signal transducer and activator of transcription 3; HWE, Hardy-Weinberg equilibrium.

Additional analysis revealed that the $\mathrm{C} / \mathrm{C}$ genotype was more frequent in invasive, recurrent and active PA subgroups compared with the healthy controls (18.8 vs. $2.5 \%, \mathrm{P}=0.041$; 19.4 vs. $2.5 \%, \mathrm{P}=0.047 ; 15.0$ vs. $2.5 \%, \mathrm{P}<0.001$, respectively; Tables VI, VII and VIII).

The FGFR2 rs2981582 G/G genotype was less frequently observed in the non-invasive PA subgroup compared with the healthy controls ( 27.6 vs. $41.6 \%$, respectively; $\mathrm{P}=0.038$ ), but the G/A genotype was more frequently observed in the non-invasive PA subgroup compared with the control group (72.4 vs. $53.1 \%$, respectively; $\mathrm{P}=0.004)$ and the invasive PA subgroup (72.4 vs. $49.4 \%$ respectively; $\mathrm{P}=0.009)$ (Table VI).
Statistical analysis was performed to evaluate the FGFR2 $r s 2981582$ association with PA activity and recurrence (Tables VII and VIII). This analysis did not reveal any association between SNP and active or non-active PA, and PA without recurrence or with recurrence.

The STAT3 rs 744166 G/G genotype was less frequently observed in invasive, non-recurrent and active PA subgroups compared with healthy controls (4.7 vs. 19.1\%, $\mathrm{P}<0.001 ; 6.2$ vs. $19.1 \%, \mathrm{P}<0.001 ; 8.8$ vs. $19.1 \%, \mathrm{P}=0.022$, respectively).

The STAT3 rs744166 A/A genotype was more frequent in the active PA subgroup compared with the control group (48.8 vs. $36.0 \%$, respectively; $\mathrm{P}=0.029$ ). There were 
Table IX. Binomial logistic regression analysis in non-invasive and invasive PA, and the control group.

\begin{tabular}{|c|c|c|c|c|c|c|}
\hline Gene & PA subgroup & Model & Genotype & OR $(95 \% \mathrm{CI})$ & P-value & AIC \\
\hline \multirow[t]{12}{*}{ SIRT1 rs12778366 } & \multirow[t]{6}{*}{ Non-invasive } & \multirow[t]{3}{*}{ Co-dominant } & $\mathrm{T} / \mathrm{T}$ & 1.000 & & 390.145 \\
\hline & & & $\mathrm{T} / \mathrm{C}$ & $0.000(0.000)$ & 0.996 & \\
\hline & & & $\mathrm{C} / \mathrm{C}$ & $7.571(3.426-16.734)$ & $<0.001$ & \\
\hline & & \multirow[t]{2}{*}{ Recessive } & $\mathrm{T} / \mathrm{T}+\mathrm{T} / \mathrm{C}$ & 1.000 & & 406.092 \\
\hline & & & $\mathrm{C} / \mathrm{C}$ & $9.221(4.175-20.367)$ & $<0.001$ & \\
\hline & & Additive & - & $1.649(1.065-2.554)$ & 0.025 & 425.148 \\
\hline & \multirow[t]{6}{*}{ Invasive } & \multirow[t]{3}{*}{ Co-dominant } & $\mathrm{T} / \mathrm{T}$ & 1.000 & & 509.448 \\
\hline & & & $\mathrm{T} / \mathrm{C}$ & $0.000(0.000)$ & 0.996 & \\
\hline & & & $\mathrm{C} / \mathrm{C}$ & $7.501(3.715-15.147)$ & $<0.001$ & \\
\hline & & \multirow[t]{2}{*}{ Recessive } & $\mathrm{T} / \mathrm{T}+\mathrm{T} / \mathrm{C}$ & 1.000 & & 533.418 \\
\hline & & & $\mathrm{C} / \mathrm{C}$ & $9.136(4.528-18.434)$ & $<0.001$ & \\
\hline & & Additive & - & $1.616(1.120-2.330)$ & 0.010 & 459.515 \\
\hline \multirow[t]{7}{*}{ FGFR2 rs2981582 } & \multirow[t]{7}{*}{ Non-invasive } & \multirow[t]{3}{*}{ Co-dominant } & $\mathrm{G} / \mathrm{G}$ & 1.000 & & 419.170 \\
\hline & & & $\mathrm{G} / \mathrm{A}$ & $2.056(1.136-3.721)$ & 0.017 & \\
\hline & & & $\mathrm{A} / \mathrm{A}$ & $0.000(0.000)$ & 0.998 & \\
\hline & & \multirow[t]{2}{*}{ Dominant } & $\mathrm{G} / \mathrm{G}$ & 1.000 & & 425.028 \\
\hline & & & $\mathrm{G} / \mathrm{A}+\mathrm{A} / \mathrm{A}$ & $1.869(1.033-3.380)$ & 0.039 & \\
\hline & & \multirow[t]{2}{*}{ Over-dominant } & $\mathrm{G} / \mathrm{G}+\mathrm{A} / \mathrm{A}$ & 1.000 & & 420.961 \\
\hline & & & $\mathrm{G} / \mathrm{A}$ & $2.319(1.283-4.193)$ & 0.005 & \\
\hline \multirow[t]{6}{*}{ STAT3 rs744166 } & \multirow[t]{6}{*}{ Invasive } & \multirow[t]{3}{*}{ Co-dominant } & $\mathrm{A} / \mathrm{A}$ & 1.000 & & 553.313 \\
\hline & & & $\mathrm{G} / \mathrm{A}$ & $1.002(0.630-1.595)$ & 0.993 & \\
\hline & & & $\mathrm{G} / \mathrm{G}$ & $0.210(0.073-0.601)$ & 0.004 & \\
\hline & & \multirow[t]{2}{*}{ Recessive } & $\mathrm{A} / \mathrm{A}+\mathrm{G} / \mathrm{A}$ & 1.000 & & 551.313 \\
\hline & & & $\mathrm{G} / \mathrm{G}$ & $0.210(0.076-0.581)$ & 0.003 & \\
\hline & & Additive & - & $0.651(0.467-0.908)$ & 0.011 & 558.771 \\
\hline
\end{tabular}

PA, pituitary adenoma; SIRT1, sirtuin 1; FGFR2, fibroblast growth factor receptor 2; STAT3, signal transducer and activator of transcription 3; OR, odds ratio; CI, confidence interval; AIC, Akaike Information Criterion.

differences between non-invasive and invasive, non-recurrent and recurrent PA subgroups as well, with the exception of comparing inactive and active PA. The STAT3 rs744166 G/G genotype was more frequent in non-invasive PA compared with invasive $\mathrm{PA}$ (15.5 vs. $4.7 \%$, respectively; $\mathrm{P}=0.038$ ) and in recurrent $\mathrm{PA}$ group comparing to non-recurrent $\mathrm{PA}$ (19.4 vs. 6.2\%, respectively; $\mathrm{P}=0.036$ ) (Tables VI-VIII).

Binomial logistic regression analysis of the control group and the PA patients by different PA subgroups. Binomial logistic regression analysis in the non-invasive PA, invasive PA and control groups was performed (Table IX). Analysing the SIRT1 polymorphism in non-invasive PA group and control group this analysis showed that the co-dominant $(\mathrm{P}<0.001)$, recessive $(\mathrm{P}<0.001)$ and additive $(\mathrm{P}=0.025)$ variables were significant. Binomial logistic regression analysis in the patients with invasive PA and the control group revealed significance of the same co-dominant $(\mathrm{P}<0.001)$, recessive $(\mathrm{P}<0.001)$ and additive $(\mathrm{P}=0.010)$ variables (Table IX).

Binomial logistic regression analysis of FGFR2 $r s 2981582$ in the non-invasive PA and control groups showed that the co-dominant $(\mathrm{P}=0.017)$, dominant $(\mathrm{P}=0.039)$ and over-dominant $(\mathrm{P}=0.005)$ variables were significant, but this analysis in the patients with invasive PA and the control group did not reveal any significance of these models.

Binomial logistic regression analysis of STAT3 rs744166 was also performed (Table IX). The analysis showed that the co-dominant $(\mathrm{P}=0.004)$, recessive $(\mathrm{P}=0.003)$ and additive $(\mathrm{P}=0.011)$ variables were statistically significant only in the invasive PA and control groups (Table IX).

Binomial logistic regression analysis in the inactive PA and control groups, and in the active PA and control groups, was performed for all 3 SNPs (Table X).

Inactive PA group analysis of SIRT1 rs12778366 showed that the co-dominant $(\mathrm{P}<0.001)$, recessive $(\mathrm{P}<0.001)$ and additive $(\mathrm{P}<0.001)$ variables were significant. The analysis of the active $\mathrm{PA}$ group revealed significance in the co-dominant $(\mathrm{P}<0.001)$ and recessive $(\mathrm{P}<0.001)$ models (Table $\mathrm{X})$.

Binomial logistic regression analysis of FGFR2 rs2981582 was performed in the inactive PA, active PA and control groups, but this analysis did not reveal significance in these models.

STAT3 rs744166 analysis in the inactive PA group showed that there were no significant variables. Analysing the active PA group, the present study revealed significance 
Table X. Binomial logistic regression analysis in inactive and active PA, and control groups.

\begin{tabular}{|c|c|c|c|c|c|c|}
\hline Gene & PA subgroup & Model & Genotype & OR $(95 \% \mathrm{CI})$ & P-value & AIC \\
\hline \multirow[t]{11}{*}{ SIRT1 rs 12778366} & \multirow[t]{6}{*}{ Inactive } & \multirow[t]{3}{*}{ Co-dominant } & $\mathrm{T} / \mathrm{T}$ & 1.000 & & \multirow[t]{3}{*}{402.990} \\
\hline & & & $\mathrm{T} / \mathrm{C}$ & $0.000(0.000)$ & 0.996 & \\
\hline & & & $\mathrm{C} / \mathrm{C}$ & $10.109(4.868-20.996)$ & $<0.001$ & \\
\hline & & \multirow[t]{2}{*}{ Recessive } & $\mathrm{T} / \mathrm{T}+\mathrm{T} / \mathrm{C}$ & 1.000 & & \multirow[t]{2}{*}{419.306} \\
\hline & & & $\mathrm{C} / \mathrm{C}$ & $12.312(5.933-25.552)$ & $<0.001$ & \\
\hline & & Additive & - & $2.045(1.388-3.015)$ & $<0.001$ & 444.842 \\
\hline & \multirow[t]{5}{*}{ Active } & \multirow[t]{3}{*}{ Co-dominant } & $\mathrm{T} / \mathrm{T}$ & 1.000 & & \multirow[t]{3}{*}{497.635} \\
\hline & & & $\mathrm{T} / \mathrm{C}$ & $0.000(0.000)$ & 0.996 & \\
\hline & & & $\mathrm{C} / \mathrm{C}$ & $5.709(2.675-12.183)$ & $<0.001$ & \\
\hline & & \multirow[t]{2}{*}{ Recessive } & $\mathrm{T} / \mathrm{T}+\mathrm{T} / \mathrm{C}$ & 1.000 & & \multirow[t]{2}{*}{521.245} \\
\hline & & & $\mathrm{C} / \mathrm{C}$ & $6.953(3.260-14.828)$ & $<0.001$ & \\
\hline \multirow[t]{8}{*}{ STAT3 rs744166 } & \multirow[t]{8}{*}{ Active } & \multirow[t]{3}{*}{ Co-dominant } & $\mathrm{A} / \mathrm{A}$ & 1.000 & & \multirow[t]{3}{*}{535.474} \\
\hline & & & $\mathrm{G} / \mathrm{A}$ & $0.669(0.430-1.135)$ & 0.148 & \\
\hline & & & $\mathrm{G} / \mathrm{G}$ & $0.339(0.148-.0776)$ & 0.010 & \\
\hline & & \multirow[t]{2}{*}{ Dominant } & $\mathrm{A} / \mathrm{A}$ & 1.000 & & \multirow[t]{2}{*}{536.765} \\
\hline & & & $\mathrm{G} / \mathrm{A}+\mathrm{G} / \mathrm{G}$ & $0.592(0.373-0.939)$ & 0.026 & \\
\hline & & \multirow[t]{2}{*}{ Recessive } & $\mathrm{A} / \mathrm{A}+\mathrm{G} / \mathrm{A}$ & 1.000 & & \multirow[t]{2}{*}{535.576} \\
\hline & & & $\mathrm{G} / \mathrm{G}$ & $0.407(0.184-0.902)$ & 0.027 & \\
\hline & & Additive & - & $0.622(0.442-0.887)$ & 0.007 & 533.914 \\
\hline
\end{tabular}

PA, pituitary adenoma; SIRT1, sirtuin 1; STAT3, signal transducer and activator of transcription 3; OR, odds ratio; CI, confidence interval; AIC, Akaike Information Criterion.

Table XI. Binomial logistic regression analysis in non-recurrent and recurrent PA and control groups.

\begin{tabular}{|c|c|c|c|c|c|c|}
\hline Gene & PA subgroup & Model & Genotype & OR $(95 \% \mathrm{CI})$ & P-value & AIC \\
\hline \multirow[t]{11}{*}{ SIRT1 rs 12778366} & Non-recurrent & Co-dominant & $\mathrm{T} / \mathrm{T}$ & 1.000 & & 614.042 \\
\hline & & & $\mathrm{T} / \mathrm{C}$ & $0.000(0.000)$ & 0.995 & \\
\hline & & & $\mathrm{C} / \mathrm{C}$ & $7.465(3.896-14.307)$ & $<0.001$ & \\
\hline & & Recessive & $\mathrm{T} / \mathrm{T}+\mathrm{T} / \mathrm{C}$ & 1.000 & & 645.812 \\
\hline & & & $\mathrm{C} / \mathrm{C}$ & $9.092(4.748-17.411)$ & $<0.001$ & \\
\hline & & Additive & - & 1.592 (1.153-2.199) & 0.005 & 678.223 \\
\hline & Recurrent & Co-dominant & $\mathrm{T} / \mathrm{T}$ & 1.000 & & 247.718 \\
\hline & & & $\mathrm{T} / \mathrm{C}$ & $0.000(0.000)$ & 0.996 & \\
\hline & & & $\mathrm{C} / \mathrm{C}$ & $7.764(2.868-21.019)$ & $<0.001$ & \\
\hline & & Recessive & $\mathrm{T} / \mathrm{T}+\mathrm{T} / \mathrm{C}$ & 1.000 & & 255.407 \\
\hline & & & $\mathrm{C} / \mathrm{C}$ & $9.456(3.495-25.586)$ & $<0.001$ & \\
\hline \multirow[t]{6}{*}{ STAT3 rs 744166} & Non-recurrent & Co-dominant & $\mathrm{A} / \mathrm{A}$ & 1.000 & & 673.559 \\
\hline & & & $\mathrm{G} / \mathrm{A}$ & $0.916(0.606-1.385)$ & 0.678 & \\
\hline & & & $\mathrm{G} / \mathrm{G}$ & $0.270(0.119-0.610)$ & 0.002 & \\
\hline & & Recessive & $\mathrm{A} / \mathrm{A}+\mathrm{G} / \mathrm{A}$ & 1.000 & & 671.731 \\
\hline & & & $\mathrm{G} / \mathrm{G}$ & $0.283(0.129-0.621)$ & 0.002 & \\
\hline & & Additive & - & $0.653(0.487-0.876)$ & 0.005 & 677.047 \\
\hline
\end{tabular}

PA, pituitary adenoma; SIRT1, sirtuin 1; STAT3, signal transducer and activator of transcription 3; OR, odds ratio; CI, confidence interval; Akaike Information Criterion.

in the co-dominant $(\mathrm{P}=0.010)$, dominant $(\mathrm{P}=0.026)$, recessive $(\mathrm{P}=0.027)$ and additive $(\mathrm{P}=0.007)$ models (Table $\mathrm{X})$.
Additional binomial logistic regression analysis of SNPs was performed in non-recurrence, recurrence and control 
groups. The analysis in the non-recurrent PA and control groups showed that the co-dominant $(\mathrm{P}<0.001)$, recessive $(\mathrm{P}<0.001)$ and additive $(\mathrm{P}=0.005)$ variables were statistically significant (Table XI). In the analysis of PA with recurrence, the co-dominant $(\mathrm{P}<0.001)$ and recessive $(\mathrm{P}<0.001)$ variables were also significant.

FGFR2 rs2981582 polymorphism analysis did not show any statistical significance.

Binomial logistic regression analysis of STAT3 rs744166 in the non-recurrent and recurrent PA groups, and the control group was performed. This revealed that in the non-recurrent $\mathrm{PA}$ and control groups, the co-dominant $(\mathrm{P}=0.002)$, recessive $(\mathrm{P}=0.002)$ and additive $(\mathrm{P}=0.005)$ variables were significant (Table XI). In the analysis of PA with recurrence there were no statistically significant variables.

\section{Discussion}

The impact of SIRT1, FGFR2 and STAT3 gene polymorphisms on the development of various tumours has been analysed in numerous studies $(38,42-52,60,63-65)$, but no studies have investigated the associations with PA development, invasiveness, activity and recurrence.

A study conducted by Rizk et al (37) investigated SIRTI gene single nucleotide polymorphism rs12778366 in patients with breast cancer, revealing that the SIRT1 rs12778366 $\mathrm{T} / \mathrm{T}$ genotypes were more frequent, exhibited higher SIRT1 levels than the $\mathrm{C} / \mathrm{C}$ and $\mathrm{C} / \mathrm{T}$ genotypes, and were associated with histological grade and lymph node status. The $\mathrm{T}$ allele frequency was higher in patients with breast cancer compared with that in normal subjects.

The present study was the first to assess the association between SIRT1 rs 12778366 and PA. It was found that the $\mathrm{T} / \mathrm{C}$ genotype was less frequent in the PA group compared with the healthy controls ( 0 vs. $17.5 \%$, respectively; $\mathrm{P}<0.001)$ and that the $\mathrm{C} / \mathrm{C}$ genotype was more frequent in the PA group compared with the healthy control group (18.9 vs. $2.5 \%, \mathrm{P}<0.001)$.

Numerous studies have investigated the FGFR2 $r s 2981582$ polymorphism in breast cancer patients, and have provided controversial data on the impact of this polymorphism on tumour development. Chen et al (43) revealed that the G/A and A/A genotypes of FGFR2 rs2981582 were associated with lower mammographic density and a reduced risk of breast cancer, and Butt et al (42) revealed a statistically significant association between the FGFR2 rs2981582 A/A genotype and breast cancer risk. Shan et al (66) also revealed that patients with the A/A genotype of FGFR2 $r s 2981582$ exhibited an increased risk of breast cancer, while Ledwon et al (47) revealed that the rs2981582 SNP showed significant association with the familial and sporadic types of breast cancer. On the basis of these findings, the present study aimed to examine whether the polymorphism in the FGFR2 promoter may affect the risk of PA development, activity, recurrence or invasiveness. No differences in genotype (G/G, G/A and A/A) distribution were observed between the control and PA groups (41.6 vs. 39.2\%, 53.1 vs. $58.7 \%$, and 5.3 vs. $2.1 \%$, respectively; $\mathrm{P}=0.174)$. No significant differences were observed between genotype distribution according to gender, PA activity, invasiveness or recurrence.
Several studies have analysed the STAT3 rs744166 polymorphism in association with various types of tumour, but none have investigated the association between STAT3 rs744166 and PA. Rocha et al (61) reported that the $r s 744166$ polymorphic $\mathrm{G}$ allele was associated with gastric cancer, and a significantly decreased risk of non-small cell lung cancer was observed for carriers of STAT3 rs744166 in a study by Jiang et al (64). The present study demonstrated the differences in the distribution of the STAT3 rs744166 polymorphism between patients with $\mathrm{PA}$ and control group subjects $(\mathrm{P}=0.012)$. The $\mathrm{G} / \mathrm{G}$ genotype was less frequent in the PA group compared with the healthy controls (9.1 vs. 19.1\%, respectively; $\mathrm{P}=0.003$ ). Analysis in different PA subgroups showed that the STAT3 rs744166 G/G genotype was more frequent in non-invasive PA compared with invasive PA (15.5 vs. $4.7 \%$; $\mathrm{P}=0.038)$ and in recurrent $\mathrm{PA}$ compared with the non-recurrent PA (19.4 vs. 6.2\%, respectively; $\mathrm{P}=0.036)$.

Overall, the present study demonstrated that the SNPs SIRT1 rs12778366 and STAT3 require replication in future larger studies, particularly with increased sample sizes to confirm the association of SIRT1 and STAT3 in patients with PA.

\section{Acknowledgements}

The present study received funding from the Research Council of Lithuania (grant no. MIP-008/2014).

\section{References}

1. Ezzat S, Asa SL, Couldwell WT, Barr CE, Dodge WE, Vance ML and McCutcheon IE: The prevalence of pituitary adenomas: A systematic review. Cancer 101: 613-619, 2004.

2. Colao A, Di Somma C, Pivonello R, Faggiano A Lombardi G and Savastano S: Medical therapy for clinically non-functioning pituitary adenomas. Endocr Relat Cancer 15: 905-915, 2008.

3. Kasputytė R, Slatkevičienė G, Liutkevičienė R, Glebauskienė B, Bernotas $\mathrm{G}$ and Tamašauskas $\mathrm{A}$ : Changes of visual functions in patients with pituitary adenoma. Medicina (Kaunas) 49: 132-137, 2013.

4. Knosp E, Steiner E, Kitz K and Matula C: Pituitary adenomas with invasion of the cavernous sinus space: A magnetic resonance imaging classification compared with surgical findings. Neurosurgery 33: 610-618, 1993.

5. Ferrante E, Ferraroni M, Castrignanò T, Menicatti L, Anagni M, Reimondo G, Del Monte P, Bernasconi D, Loli P, Faustini-Fustini M, et al: Non-functioning pituitary adenoma database: A useful resource to improve the clinical management of pituitary tumours. Eur J Endocrinol 155: 823-829, 2006.

6. Ahmadi J, North CM, Segall HD, Zee CS and Weiss MH: Cavernous sinus invasion by pituitary adenomas. Am J Neuroradiol 6: 893-898, 1985.

7. Falbusch R and Buchfejder M: Transsphenoidal surgery of parasellar pituitary adenomas. Acta Neurochir 92: 93-99, 1988.

8. Scheithauer BW, Kovacs KT, Laws ER Jr and Randall RV: Pathology of invasive pituitary tumors with special reference to functional classification. J Neurosurg 65: 733-744, 1986.

9. Moon CH, Hwang SC, Kim BT, Ohn YH and Park TK: Visual prognostic value of optical coherence tomography and photopic negative response in chiasmal compression. Invest Ophthalmol Vis Sci 52: 8527-8533, 2011.

10. Thomas R, Shenoy K, Seshadri MS, Muliyil J, Rao A and Paul P: Visual field defects in non-functioning pituitary adenomas. Indian J Ophthalmol 50: 127-130, 2002.

11. Trautmann JC and Laws ER Jr: Visual status after transphenoidal surgery at the Mayo Clinic 1971-1982. Am J Ophthalmol 96: 200-208, 1983.

12. Kaur A, Banerji D, Kumar D and Sharma K: Visual status in suprasellar pituitary tumours. Indian J Ophthalmol 43: 131-134, 1995 
13. Mortini P, Losa M, Barzaghi R, Boari N and Giovanelli M: Results of transsphenoidal surgery in a large series of patients with pituitary adenoma. Neurosurgery 56: 1222-1233, 2005.

14. el-Azouzi M, Black PM, Candia G, Zervas NT and Panagopoulos KP: Transsphenoidal surgery for visual loss in patients with pituitary adenomas. Neurol Res 12: 23-25, 1990.

15. Marazuela M, Astigarraga B, Vicente A, Estrada J, Cuerda C, Garcia-Uria J and Lucas T: Recovery of visual and endocrine function following transsphenoidal surgery of large nonfunctioning pituitary adenomas. J Endocrinol Invest 17: 703-707, 1994

16. Gondim JA, de Almeida JP, de Albuquerque LA, Schops M, Gomes E and Ferraz T: Headache associated with pituitary tumors. J Headache Pain 10: 15-20, 2009.

17. Levy MJ, Jäger H, Powell M, Matharu MS, Meeran K and Goadsby PJ: Pituitary volume and headache: Size is not everything. Arch Neurol 61: 721-725, 2004.

18. Stevens JM, Valentine AR and Kendall BE: Computed cranial and spinal imaging. A practical introduction. Lippincott Williams \& Wilkins, Philadelphia, PA, pp154-156, 1988.

19. Wilson CB: Neurosurgical management of large and invasive pituitary tumors. In: Clinical management of pituitary disorders. Tindall GT, Collins WF (eds). Raven, New York, NY, pp335-342, 1979.

20. Luo JC, Peng YL, Chen TS, Huo TI, Hou MC, Huang HC, Lin $\mathrm{HC}$ and Lee FY: Clopidogrel inhibits angiogenesis of gastric ulcer healing via down regulation of vascular endothelial growth factor receptor 2. J Formos Med Assoc 115: 764-772, 2016.

21. Lu J, Zhang L, Chen X, Lu Q, Yang Y, Liu J and Ma X: SIRT1 counteracted the activation of STAT3 and NF- $\kappa \mathrm{B}$ to repress the gastric cancer growth. Int J Clin Exp Med 7: 5050-5058, 2014

22. Nie Y, Erion DM, Yuan Z, Dietrich M, Shulman GI, Horvath TL and Gao Q: STAT3 inhibition of gluconeogenesis is downregulated by SirT1. Nat Cell Biol 11: 492-500, 2009.

23. Bernier M, Paul RK, Martin-Montalvo A, Scheibye-Knudsen M, Song S, He HJ, Armour SM, Hubbard BP, Bohr VA, Wang L, et al: Negative regulation of STAT3 protein-mediated cellular respiration by SIRT1 protein. J Biol Chem 286: 19270-19279, 2011.

24. Imai S, Armstrong CM, Kaeberlein M and Guarente L: Transcriptional silencing and longevity protein Sir2 is an NAD-dependent histone deacetylase. Nature 403: 795-800, 2000.

25. Cohen HY, Miller C, Bitterman KJ, Wall NR, Hekking B, Kessler B, Howitz KT, Gorospe M, de Cabo R and Sinclair DA: Calorie restriction promotes mammalian cell survival by inducing the SIRT1 deacetylase. Science 305: 390-392, 2004

26. Vaziri H, Dessain SK, Ng Eaton E, Imai SI, Frye RA, Pandita TK, Guarente L and Weinberg RA: hSIR2(SIRT1) functions as an NAD-dependent p53 deacetylase. Cell 107: 149-159, 2001.

27. Chen WY, Wang DH, Yen RC, Luo J, Gu W and Baylin SB: Tumor suppressor HIC1 directly regulates SIRT1 to modulate p53-dependent DNA-damage responses. Cell 123: 437-448, 2005.

28. Motta MC, Divecha N, Lemieux M, Kamel C, Chen D, Gu W, Bultsma Y, McBurney M and Guarente L: Mammalian SIRT1 represses forkhead transcription factors. Cell 116: 551-563, 2004

29. Chen HC, Jeng YM, Yuan RH, Hsu HC and Chen YL: SIRT1 promotes tumorigenesis and resistance to chemotherapy in hepatocellular carcinoma and its expression predicts poor prognosis. Ann Surg Oncol 19: 2011-2019, 2012.

30. Sung JY, Kim R, Kim JE and Lee J: Balance between SIRT1 and DBC1 expression is lost in breast cancer. Cancer Sci 101: $1738-1744,2010$

31. Huffman DM, Grizzle WE, Bamman MM, Kim JS, Eltoum IA, Elgavish A and Nagy TR: SIRT1 is significantly elevated in mouse and human prostate cancer. Cancer Res 67: 6612-6618, 2007.

32. Jang KY, Kim KS, Hwang SH, Kwon KS, Kim KR, Park HS Park BH, Chung MJ, Kang MJ, Lee DG and Moon WS: Expression and prognostic significance of SIRT1 in ovarian epithelial tumours. Pathology 41: 366-371, 2009.

33. Cha EJ, Noh SJ, Kwon KS, Kim CY, Park BH, Park HS, Lee H, Chung MJ, Kang MJ, Lee DG, et al: Expression of DBC1 and SIRT1 is associated with poor prognosis of gastric carcinoma. Clin Cancer Res 15: 4453-4459, 2009.

34. Stunkel W, Peh BK, Tan YC, Nayagam VM, Wang X, Salto-Tellez M, Ni B, Entzeroth M and Wood J: Function of the SIRT1 protein deacetylase in cancer. Biotechnol J 2: 1360-1368, 2007.

35. Liu G, Yuan X, Zeng Z, Tunici P, Ng H, Abdulkadir IR, Lu L, Irvin D, Black KL and Yu JS: Analysis of gene expression and chemoresistance of CD133+ cancer stem cells in glioblastoma. Mol Cancer 5: 67, 2006
36. Jang KY, Hwang SH, Kwon KS, Kim KR, Choi HN, Lee NR, Kwak JY, Park BH, Park HS, Chung MJ, et al: SIRT1 expression is associated with poor prognosis of diffuse large B-cell lymphoma. Am J Surg Pathol 32: 1523-1531, 2008.

37. Rizk SM, Shahin NN and Shaker OG: Association between SIRT1 gene polymorphisms and breast cancer in Egyptians. PLoS One 11: e0151901, 2016.

38. Wesche J, Haglund K and Haugsten EM: Fibroblast growth factors and their receptors in cancer. Biochem J 437: 199-213, 2011

39. Marzioni D, Lorenzi T, Mazzucchelli R, Capparuccia L, Morroni M, Fiorini R, Bracalenti C, Catalano A, David G, Castellucci M, et al: Expression of basic fibroblast growth factor, its receptors and syndecans in bladder cancer. Int J Immunopathol Pharmacol 22: 627-638, 2009

40. Davies H, Hunter C, Smith R, Stephens P, Greenman C, Bignell G, Teague J, Butler A, Edkins S, Stevens C, et al: Somatic mutations of the protein kinase gene family in human lung cancer. Cancer Res 65: 7591-7595, 2005.

41. Bayraktar S, Thompson PA, Yoo SY, Do KA, Sahin AA, Arun BK, Bondy ML and Brewster AM: The relationship between eight GWAS-identified single-nucleotide polymorphisms and primary breast cancer outcomes. Oncologist 18: 493-500, 2013

42. Butt S, Harlid S, Borgquist S, Ivarsson M, Landberg G, Dillner J, Carlson J and Manjer J: Genetic predisposition, parity, age at first childbirth and risk for breast cancer. BMC Res Notes 5: 414, 2012.

43. Chen Y, Shi C and Guo Q: TNRC9 rs12443621 and FGFR2 rs2981582 polymorphisms and breast cancer risk. World J Surg Oncol 14: 50, 2016

44. Cui F, Wu D, Wang W, He X and Wang M: Variants of FGFR2 and their associations with breast cancer risk: a HUGE systematic review and meta-analysis. Breast Cancer Res Treat 155: 313-335, 2016.

45. Campa D, Barrdahl M, Gaudet MM, Black A, Chanock SJ, Diver WR, Gapstur SM, Haiman C, Hankinson S, Hazra A, et al: Genetic risk variants associated with in situ breast cancer. Breast Cancer Res 17: 82, 2015.

46. Siddiqui S, Chattopadhyay S, Akhtar MS, Najm MZ, Deo SV, Shukla NK and Husain SA: A study on genetic variants of fibroblast growth factor receptor 2 (FGFR2) and the risk of breast cancer from North India. PLoS One 9: e110426, 2014.

47. Ledwoń JK, Hennig EE, Maryan N, Goryca K, Nowakowska D, Niwińska A and Ostrowski J: Common low-penetrance risk variants associated with breast cancer in Polish women. BMC Cancer 13: 510, 2013.

48. Murillo-Zamora E, Moreno-Macías H, Ziv E, Romieu I, Lazcano-Ponce E, Ángeles-Llerenas A, Pérez-Rodríguez E, Vidal-Millán S, Fejerman L and Torres-Mejía G: Association between rs2981582 polymorphism in the FGFR2 gene and the risk of breast cancer in Mexican women. Arch Med Res 44: 459-466, 2013.

49. Ottini L, Silvestri V, Saieva C, Rizzolo P, Zanna I, Falchetti M, Masala G, Navazio AS, Graziano V, Bianchi S, et al: Association of low-penetrance alleles with male breast cancer risk and clinicopathological characteristics: Results from a multicenter study in Italy. Breast Cancer Res 138: 861-868, 2013.

50. Jara L, Gonzalez-Hormazabal P, Cerceño K, Di Capua GA, Reyes JM, Blanco R, Bravo T, Peralta O, Gomez F, Waugh E, et al: Genetic variants in FGFR2 and MAP3K1 are associated with the risk of familial and early-onset breast cancer in a South-American population. Breast Cancer Res Treat 137: 559-569, 2013.

51. Miles FL, Rao JY, Eckhert C, Chang SC, Pantuck A and Zhang ZF: Associations of immunity-related single nucleotide polymorphisms with overall survival among prostate cancer patients. Int J Clin Exp Med 8: 11470-11476, 2015.

52. Yu H, Kortylewski M and Pardoll D: Crosstalk between cancer and immune cells: Role of STAT3 in the tumour microenvironment. Nat Rev Immunol 7: 41-51, 2007.

53. Yu H, Pardoll D and Jove R: STATs in cancer inflammation and immunity: a leading role for STAT3. Nat Rev Cancer 9: 798-809, 2009.

54. Niu G, Wright KL, Huang M, Song L, Haura E, Turkson J, Zhang S, Wang T, Sinibaldi D, Coppola D, et al: Constitutive Stat3 activity up-regulates VEGF expression and tumor angiogenesis. Oncogene 21: 2000-2008, 2002.

55. Kusaba T, Nakayama T, Yamazumi K, Yakata Y, Yoshizaki A, Nagayasu T and Sekine I: Expression of p-STAT3 in human colorectal adenocarcinoma and adenoma; correlation with clinicopathological factors. J Clin Pathol 58: 833-838, 2005. 
56. He G and Karin M: NF- $\kappa \mathrm{B}$ and STAT3-key players in liver inflammation and cancer. Cell Res 21: 159-168, 2011.

57. Pandey MK, Sung B and Aggarwal BB: Betulinic acid suppresses STAT3 activation pathway through induction of protein tyrosine phosphatase SHP-1 in human multiple myeloma cells. Int J Cancer 127: 282-1392, 2010.

58. Gariboldi MB, Ravizza R and Monti E: The IGFR1 inhibitor NVP-AEW541 disrupts a pro-survival and pro-angiogenic IGF-STAT3-HIF1 pathway in human glioblastoma cells. Biochem Pharmacol 80: 455-462, 2010.

59. Shin J, Lee HJ, Jung DB, Jung JH, Lee HJ, Lee EO, Lee SG, Shim BS, Choi SH, Ko SG, et al: Suppression of STAT3 and HIF-1 alpha mediates anti-angiogenic activity of betulinic acid in hypoxic PC-3 prostate cancer cells. PLoS One 6: e21492, 2011.

60. Leeman-Neill RJ, Wheeler SE, Singh SV, Thomas SM, Seethala RR, Neill DB, Panahandeh MC, Hahm ER, Joyce SC, Sen M, et al: Guggulsterone enhances head and neck cancer therapies via inhibition of signal transducer and activator of transcription-3. Carcinogenesis 30: 1848-1856, 2009.

61. Rocha GA, Rocha AM, Gomes AD, Faria CL Jr, Melo FF Batista SA, Fernandes VC, Almeida NB, Teixeira KN, Brito KS and Queiroz DM: STAT3 polymorphism and helicobacter pylori CagA strains with higher number of EPIYA-C segments independently increase the risk of gastric cancer. BMC Cancer 15: $528,2015$.
62. Yuan K, Liu H, Huang L, Ren X, Liu J, Dong X, Tian W and Jia Y: rs744166 polymorphism of the STAT3 gene is associated with risk of gastric cancer in a Chinese population. Biomed Res Int 2014: 527918, 2014.

63. Ryan BM, Wolff RK, Valeri N, Khan M, Robinson D, Paone A, Bowman ED, Lundgreen A, Caan B, Potter J, et al: An analysis of genetic factors related to risk of inflammatory bowel disease and colon cancer. Cancer Epidemiol 38: 583-590, 2014

64. Jiang B, Zhu ZZ, Liu F, Yang LJ, Zhang WY, Yuan HH, Wang JG, Hu XH and Huang G: STAT3 gene polymorphisms and susceptibility to non-small cell lung cancer. Genet Mol Res 10: 1856-1865, 2011.

65. Akaike H: Information theory as an extension of the maximum likelihood principle. Petrov BN and Csaki F (eds). 2nd International Symposium on Information Theory. Akademiai Kiado, Budapest, pp267-281, 1973.

66. Shan J, Mahfoudh W, Dsouza SP, Hassen E, Bouaouina N, Abdelhak S, Benhadjayed A, Memmi H, Mathew RA, Aigha II, et al: Genome-wide association studies (GWAS) breast cancer susceptibility loci in Arabs: Susceptibility and prognostic implications in Tunisians. Breast Cancer Res Treat 135: 715-724, 2012. 